\title{
Vizualitation of Portuguese Relics in Flores of Local Historical Learning
}

\author{
Maria Florentina Tery ${ }^{*}$; Sunardi; Akhmad Arif Musadad \\ Faculty of Teacher Training and Education, Sebelas Maret University, Indonesia \\ Email: terryverha@gmail.com
}

http://dx.doi.org/10.18415/ijmmu.v5i4.288

\begin{abstract}
The past only leaves traces of the heritage, these traces are important components that should not be ignored in order to reconstruct the past itself. Visualization of historical relics around students as a learning resource in local historical learning can create an active and fun learning environment. This study aims to describes the planning, implementation of the learning process, until the evaluation of local historical learning through visualization of Portuguese relics in Flores which is made by local historical lecturer of Flores University. Based on the result of research, it can be concluded that visualization in the form of learning videos is very appropriate to be used as an alternative in packing material that is difficult to reach by the method of tour/ learning tour that is learning method by inviting learners to visit learning source in the form of objects or objects to expand knowledge, but it must be designed with both in order not to interfere with student concentration. The success rate of student learning can be measured through the evaluation result used by the lecturer in the form of assessment rubric. From the assesment analysis, the students know that the students get satisfactory value.
\end{abstract}

Keywords: Portuguese Heritage; Visualization; Local History

\section{Introduction}

The realization of the society ideals or a nation is determined by the next generation who are able to understand the history of society or nation. Understanding of history is widely implemented through education. The education is historical education. Priyadi (2012) states that seeing the reality, the writing of history always starts from the National History of Indonesia which led to the murder of local nationalism slowly. Local people should have a distinctive identity and solidarity, describing the local spirit. With the writing of history or learning history that raised events at the local level is expected to provide refreshment and stimulus for the learners of history to be more passionate in understanding and writing history.

Schools and other educational institutions are part of the community, therefore should be able to do preservation or uniqueness of the surrounding environment. It must present an educational program that can provide insight to learners about the characteristics of the region either the natural environment, social, cultural and the needs of the region, (Idi., 2007: 258). It means that educational institutions should develop educational programs that oriented on the environment, local potential and regional 
characteristics so students have an understanding of the environment. Therefore, student have basic skills then it can be developed further. Through local historical learning, students are invited to get closer to the real situation of their immediate environment. It brings the students directly recognize and appreciate the community environment which they are a part of it. From the local historical learning, students will get many examples and experiences from different levels of the community environment development, including the current situation. They will also be more motivate to develop specific skills such as observation, questioning or interviewing techniques, selecting sources, finding facts, and so on.

Widja (1989: 61) explains that once the historical event occurs then the event will disappear, it is left traces (footprints) of events that later became a source in compiling history. It is called historical relics. In line with the above opinion, the Bank; Sylvester; Mays; and Hasan, are looking forward to the use of historical sources in teaching history at school. Students must try to find evidence from past events (historical sources), cultivate or criticize the source, interpret, and then arrange it into a historical story. Teachers are no longer the only one source of information in the classroom, but play a role in many dimensions, as a student activity adviser. The student's duties are like a professional historian, though only at an introduction level. They can collect, process, interpret, and summarize sources in various ways, even the imposition of a history textbook in school can also be used as a source, depending on how to treat the source. (Purnamasari \& Wasino., 2011).

Portuguese relics in Flores are also utilized by local historical lecturers as a source of local historical learning through audiovisual media in the form of learning videos. The media used in this learning is the audio visual media that shows the elements of auditif (hearing) and visual (vision), so it can be viewed or heard (Anitah., 2009: 55). Lecturers use audiovisual media to minimize the time, given the many Portuguese relics scattered in several areas in Flores. In addition, the use of audiovisual media utilized lecturers because the limitations of reference sources of the books provided.

\section{Methodology}

This research used a qualitative descriptive approach using a single case study strategy that is focused on one single characteristic goal. In addition, because of the problems and focus of the research has been predetermined, further research strategy in the form of embedded case study. In this research, researchers examined the planning, implementation of the learning process, until the evaluation of local historical learning through visualization video learning of Portuguese relics in Flores made by local historical lecturer of Flores University.

Data and sources of research data used are head of historical education at Flores University, local historical lecturer and students who follow local historical lectures; The venue for local historical learning activities is the lecture room of historical students, as well as archives and documents in the form of learning tools, the profile of Flores University and head of historical education. Data collection techniques such as in-depth interviews, observation and documentation.

\section{Result and Discussion}

In planning local historical learning through visualization of Portuguese relics in Flores, the local historical lecturer of the Flores University provides the media, learning resources, assessment tools and learning scenarios that have been developed. With determine the character of the material as well as the condition of the learning environment, collage student need and based on the syllabus that has been developed in accordance with the applicable curriculum. This is in line with Kartodirdjo's opinion, (2014: 57) states that local historical learning by utilizing historical events surrounding students' environments 
can help students to understand and know the history of the region so it can encourage them to find out more and to review the truth of the event.

local historical learning through visualization of the Portuguese colonies in Flores is expected to give a special impression to students about the history behind the Portuguese heritage as well as encourage students to develop special skills such as observation, questioning or interviewing techniques, selecting sources, finding facts and etc.

In the implementation of local historical learning at Flores University, the lecturer uses a discussion method combined with the reaction technique to the video. Learning media in the form of learning videos is made lecturers by considering learning materials that can not be reached by students. Therefore, the media used to get closer, give a clear picture and as an intermediary learning process with teaching materials about Portuguese relics in Flores to students.

Media is anything that can be used to transfer messages from the sender to the recipient so it can stimulate students' thoughts, feelings, interests and their attention in such a way that the learning process (Sadiman., 1986: 7) takes place. Related to the understanding of the media above in local historical learning at Flores University, lecturers use audio visual media in learning. This is done by local historical lecturer in introducing Portuguese relics in Flores as a learning resource for students. To save time, effort and cost as well as other obstacles then the audio-visual media is made lecturer as its aternatif.

The use of the media include: Clarify the presentation of the message so as not too verbalitas (only words and writing); overcome the limitations of space, time and sense power; Can overcome the passive attitude of students means useful media cause excitement of learning, enabling direct interaction of students with the environment; With the uniqueness of each learner, the media can overcome this problem. They are providing the same incentive, equating experience and generating the same perception, (Sadiman., 2014: 17). Audio visual media that is used by local historical lecturer of Flores University. it is one alternative lecturer in trying to variation of learning activities in order to avoid saturation. Through the results of observation and interviews, it was found that students are very enthusiastic and active in this learning activity. There are several reasons proposed by lecturers and collage student about student enthusiasm and activeness, as follows: First, Source of learning used by lecturers comes from the history of region itself. It makes the students very enthusiastic in the discussion. Second, media are used by lecturers, I can be table to attract students' attention, because they are not boring and interesting. Three, media used are considered to represent students to see directly Portuguese relics in Flores.

There are various methods or collaborative techniques in learning, one of them is the method of reaction against video/ a reaction to video, (Warsono \& Hariyanto., 2012: 85). In this case, local historical lecturers use the technique of reaction to video/ a reaction to video in local historical learning. The lecturer prepares instructional videos relevant to the learning material.

The learning activities that is conducted, lecturers prepare learning resources related to Portuguese relics material in Flores packaged in learning video and presented by using LCD to students. In the introductory activity, the lecturer appoints one of the students to lead the prayer; lecturer checks attendance; asking students about the readiness to follow the lecture with the materials and learning activities which at the previous meeting have been delivered; lecturers prepare resources and learning media. Themain activity, according to the observer's observation in the main activity at the second meeting is similar to the learning activity at the first meeting. The student activities is following the cues described by lecturers such as; seriously pay attention and listen to instructional videos displayed; record things that are considered important; ask the lecturer about things that have not been understood; answer questions that lecturer throws to students. While the lecturers activities are giving questions to the students before the video learning playback; displaying learning videos; answer and justify answers to questions from students about things that students have not understood; throwing questions to students. 
The closing activities, lecturers and students conclude the results of the discussions. The lecturer gives one student a question to complete within the last 15 minutes to be collected and rated by the lecturer.

The local historical lecturer of Flores University has considered various things so teacher choose to make learning video. It is as an alternative in packing material that is difficult to reach by the method of tour/ study tour that is learning method by inviting learners to visit learning source in the form of object or object to expand knowledge. Majid (2013: 60) states that in the media selection should pay attention to things such as the characteristics of learners; learning objectives; performance context; target; assessment requirements and other considerations are not less important when it was deciding to use the media. Teacher must ensure that the selected media available in the learning environment.

Local historical lecturer of Flores University utilize media to bring students closer to learning source which is difficult to reach so students is better understand the material. This is evidenced by the recognition of students about the level of their understanding of the material taught by lecturers using the media and learning resources presented. The benefits of various media and learning resources is avoiding communication failure means that the subject matter given by the teacher can be accepted by the students optimally so there is no wrong response (Sanjaya., 2006: 162). Another ability in the implementation of learning that needs to be mastered by the teacher is using media and learning resources.

Evaluation of local historical learning through visualization of Portuguese relics in Flores is using non-test assessment instrument in the form of rubric. In the rubric, there is a score/ grade, which is intended to know the extent to know how further the ability of the students/ students in mastering the teaching materials; writing report; solve problems or answer questions thatt are raised by teacherss. There is no standard provision on scoring/ grades in a rubric but the general provisions agreed by experts are the greater score so the more perfect the work of a student/ protege, (Warsono and Hariyanto., 2012: 279). Assessment that is used by local historical lecturer is using rubric of discussion appraisal where in rubric there are some dimension or aspect such as mastery of discussion material with maximum rating of 30; on the accuracy of solving the problem, with a maximum rating of 30; communication skills with a maximum rating of 20; the ability to answer questions with a maximum of 10 and the last accuracy with a maximum score of 10 .

\section{Conclusion}

Overall, the visualization of Portuguese relics in Flores in the learnig is very precise, in accordance with the needs of the students although some obstacles are found in the making of instructional media. The instructional videos are made by lecturers who do not have special education about IT (Information Technology), the lecturers make the video improvise according to the knowledge that lecturers obtain when lectures. Lecturers do not have special education which causes less interesting learning videos.

The use of learning resources of Portuguese relics in Flores are visualized by lecturers through video learning, which is related to the student environment is very good to be applied in the local historical. It brings the learning atmosphere more active and communicative in the learning so the goals set in the learning can be achieved well and the students get a satisfactory score.

\section{References}

Abdullah, I. (2007). Pengembangan Kurikulum. Joggyakarta: Ar-Arzz Media.

Anitah, S. (2009). Media Pembelajaran. Surakarta: Panitia Sertifikasi Guru Rayon 13 FKIP UNS. 
Kartodirjdo, S. (1987). Pengantar Sejarah Indonesia Baru: 1500-1900: dari EmporiumSampai Imperium. Yogyakarta: Penerbit Ombak.

Majid, A. (2013). Perencanaan Pembelajaran Sejarah: Pengembangan Standar Kompetensi Guru. Bandung: PT Remaja Rosdakarya.

Priyadi, S. (2012). Sejarah Lokal: Konsep, Metode, dan Tantangannya. Yogyakarta: Penerbit Ombak.

Purnamasari, I \& Wasino. (2011). Pengembangan Model Pembelajaran Sejarah Berbasis Situs Sejarah Lokal Di Sma Negeri Kabupaten Temanggung. Paramita Historical Studies Journal, 21(2). Diakses 28 Agustus 2016.

Sadiman, A. (2011). Media Pendidikan. Jakarta: Rajawali Press.

Sanjaya, H. W. (2006). Strategi Pembelajaran: Berorientasi Standar Proses Pendidikan. Jakarta: Kencana Prenadamedia Group.

Warsono \& Hariyanto. (2017). Pembelajaran Aktif. Bandung: PT Remaja Rosdakarya.

Widja, I. G. (1989). Sejarah Lokal Suatu Perspektif Dalam Pengajaran Sejarah. Jakarta: Dirjen Dikti.

\section{Copyrights}

Copyright for this article is retained by the author(s), with first publication rights granted to the journal.

This is an open-access article distributed under the terms and conditions of the Creative Commons Attribution license (http://creativecommons.org/licenses/by/4.0/). 